\title{
Setting the stage of innovations in allergy globally
}

\author{
Alessandro Fiocchi
}

This is my first editorial as the new Editor-in-Chief of the World Allergy Organization Journal (WAO Journal), and I must begin with a thank you to the previous Editor-inChief, Professor Lanny Rosenwasser. He had set for the Journal a high standard that I pledge to maintain and to develop further. During his tenure, the Journal was established as an open-access resource and became indexed in PubMed Central and PubMed as well as other open source indexes, and the number of articles increased significantly, making it a regular publication in its new online-only form. Both Professor Rosenwasser and our first Editor-in-Chief, Professor Johannes Ring, will thankfully stay involved as Founding Editors, so the Journal will have the opportunity to continue to profit from their combined experience.

In addition, I would like to reciprocate the wishes to Professor Rosenwasser [1] for a fruitful presidency. In the next two years he will lead an organization that has measurably expanded. What was done during the last presidencies to recruit excellent resources for the World Allergy Organization (WAO) is an unparalleled effort among the medical scientific societies. The team built under the presidency of Professor G. Walter Canonica, with the formation of the Special Committees, paved the way to the creation of authoritative guidelines in his time and throughout the presidencies of Professor Richard F. Lockey and Professor Ruby Pawankar. This made the organization an influential collaborator with patient organizations, regulatory authorities, and industry everywhere. During the past two years, WAO established several scientific initiatives and position papers focusing on severe and complex allergies, [2] nurtured connections with a number of national and regional allergy societies, in particular in Asia and Africa, organized high caliber scientific meetings, and promoted initiatives both in countries where allergic disease is a big health problem and in countries where it is growing in prevalence and severity [3]. This was due to the dedicated efforts of a wise leadership led by Professor Ruby Pawankar. This gave

Correspondence: allerg@tin.it

Pediatric Hospital Bambino Gesù, Piazza di Sant'Onofrio 4, Rome, Vatican City Italy

\section{() Biomed Central}

me personally the opportunity to lead an important initiative, the development of Guidelines on Atopic Disease Prevention (GLAD-P), in line with her vision which included a focus on disease prevention.

I have no doubt that the new presidency will further extend the WAO horizons. Thus, while Professor Rosenwasser is receiving a growing organization, I am taking the leadership of a very interesting and growing Journal, now entering its seventh year of publication, with a substantial number of articles covering the main topics of our discipline, i.e., (in decreasing order of citations) asthma, allergic rhinitis, food allergy, immunotherapy, and drug allergy. Most important, the WAO Journal is ready for citation analysis toward acquiring its Impact Factor.

Being the official organ of the World Allergy Organization, WAO Journal is intended to mirror the professional and academic interests of our members. It will also be a platform for viewing the development of allergic disease in the world. As a pediatric allergist active in the last 25 years, I have experienced the clinical impact of the increase of this new class of diseases: increasing number of patients, increasing complexity of cases, and new allergic pathologies. To exemplify, our generation witnessed the appearance of the Oral Allergy Syndrome [4], the Food Protein-Induced Enterocolitis Syndrome, [5] and Eosinophilic Oesophagitis [6]. As a reader of the allergy literature, I would have hardly imagined 25 years ago that in 2012 we would have 23 indexed allergy journals, with appreciable to high ranking impact factors.

The WAO Journal will profit from the tremendous advancements reflected in these journals and will attempt to keep the reader updated on the different aspects of allergy diagnosis, interpretation, and treatment. For diagnosis and treatment, in particular, the availability of molecular tools opens new avenues to a better interpretation of the disease [7], the formulation of new forms of specific immunotherapy [8], and the generation of molecular treatments able to target very specific aspects of allergic disease [9]. Specifically, the new Deputy Editor of WAO Journal, Professor Erika Jensen-Jarolim, as an expert in the field has followed the progress of diagnostics and molecular therapy since the cloning of the first allergen to the borders with 
oncology [10]. She will orient the Journal in the field of clinical interpretation of molecular-based diagnostics. This is one of the main interests of WAO, as focused on in a recent consensus document [11]. WAO is assembling a strong Editorial Board which Erika and I are proud of. It will profit from the experience of young researchers as well as of prominent scientists and former presidents of the organization. One of them, Professor Michael Kaliner (President, 2005-2007), will be Series Editor for the new section he initiated and launched, "WAO International Case-based Discussions", [12] aimed to illuminate the different perspectives of the same clinical problem from the different parts of the world.

The causes of allergy epidemics are far from being fully understood and remain a real mystery of modern life [13]. I am sure that research on the etiology and mechanisms of allergic disease (s) will be one of the major topics of WAO Journal over the next few years. In this respect, we have still to learn from epidemiologic studies that are being actively developed. The comparison among the allergy trends in the different parts of the world will be particularly interesting in this regard, and the Journal is the natural place for comparative epidemiologic studies $[14,15]$.

All active individual members of the $92 \mathrm{WAO}$ Member Societies are members of WAO. This Journal is their publication. It is your publication. Thus, I encourage you to participate in the WAO Journal endeavor to publish works with specific clinical relevance and practical measures that are critical for the practice of allergy anywhere in the world.

Received: 19 February 2014 Accepted: 20 February 2014

Published: 21 March 2014

\section{References}

1. Rosenwasser LJ: New editorial leadership of the world allergy organization journal. World Allergy Organization Journal 2014, 7:3. doi:10.1186/1939-4551-7-3.

2. Pawankar R: The unmet global health need of severe and complex allergies: meeting the challenge. World Allergy Organization Journal 2012, 5:20-21. doi:10.1097/WOX.0b013e31824a5552.

3. Pawankar R, Canonica GW, Holgate ST, Lockey RF: Allergic diseases and asthma: a major global health concern. Current Option in Allergy and Clinical Immunology 2012, 12(1):39-41. doi:10.1097/ACl.0b013e32834ec13b.

4. Orotolani C, Ispano M, Pastorello E, Bigi A, Ansaloni R: The oral allergy syndrome. Annals of Allergy 1988, 61(6 Pt2):47-52.

5. Sicherer $\mathrm{SH}$, Eigenmann PA, Sampson HA: Clinical features of food proteininduced enterocolitis syndrome. J Pediatr 1998, 133(2):214-219.

6. Lee RG: Marked eosinophilia in esophageal mucosal biopsies. Am J Surg Pathol 1985, 9(7):475-479.

7. Savi E, Peveri S, Incorvaia C, Dell'Albani I, Marcucci F, Di Cara G, Frati F: Association between a low lgE response to $\mathrm{Phl} p 5$ and absence of asthma in patients with grass pollen allergy. Clinical and Molecular Allergy 2013, 11(1):3. doi:10.1186/1476-7961-11-3.

8. Valenta R, Linhart B, Swoboda I, Niederberger V: Recombinant allergens for allergen-specific immunotherapy: 10 years anniversary of immunotherapy with recombinant allergens. Allergy 2011, 66(6):775-783. doi:10.1111/j.1398-9995.2011.02565.x.

9. Normansell R, Walker S, Milan SJ, Walters EH, Nair P: Omalizumab for asthma in adults and children. Cochrane Database Syst Rev 2014, 1, CD003559. doi:10.1002/14651858.CD003559.pub4.
10. Singer J, Jensen-Jarolim E: IgE-based immunotherapy of cancer: challenges and chances. Allergy 2013, 69(2):137-149. doi:10.1111/all.12276.

11. Canonica GW, Ansotegui IJ, Pawankar R, Schmid-Grendelmeier P, van Hage M, Baena-Cagnani CE, Melioli G, Nunes C, Passalacqua G, Rosenwasser L, Sampson H, Sastre J, Bousquet J, Zuberbier T, WAO-ARIA-GA2LEN Task Force: A WAOARIA-GA2LEN consensus document on molecular-based allergy diagnostics. World Allergy Organization Journal 2013, 6:17. doi:10.1186/1939-4551-6-17.

12. Leiding JW, Beakes D, Dreskin SC, Grumach A, Hide M, Reshef A, Triggiani $M$, Kaliner MA: 45 year-old male with recurrent angioedema: WAO international case-based discussions. World Allergy Organization Journal 2014, 7:2. doi:10.1186/1939-4551-7-2.

13. Prescott S: The Allergy Epidemic: A Mystery of Modern Life. Crawley, Western Australia: UWA Publishing; 2011.

14. Prescott SL, Pawankar R, Allen KJ, Campbell DE, Sinn JKH, Fiocchi A, Ebisawa M, Sampson HA, Beyer K, Lee BW: A global survey of changing patterns of food allergy burden in children. World Allergy Organization Journal 2013, 6:21. doi:10.1186/1939-4551-6-21.

15. Pawankar R, Baena-Cagnani CE, Bousquet J, Canonica GW, Cruz AA, Fiocchi A, Ebisawa M, Sampson HA, Beyer K, Lee B-W: State of the world allergy report 2008: allergy and chronic respiratory diseases. World Allergy Organization Journal 2008, 1(6 Suppl):s4-s17. Doi: 10.1097NOX.0b013e31817ff995.

\section{doi:10.1186/1939-4551-7-5}

Cite this article as: Fiocchi: Setting the stage of innovations in allergy globally. World Allergy Organization Journal 2014 7:5.

\section{Submit your next manuscript to BioMed Central and take full advantage of:}

- Convenient online submission

- Thorough peer review

- No space constraints or color figure charges

- Immediate publication on acceptance

- Inclusion in PubMed, CAS, Scopus and Google Scholar

- Research which is freely available for redistribution 